World Lumen Congress 2021 | May 26-30, 2021

Iasi, Romania

\title{
Psychological Well-being of First-year Psychology Students amid the COVID-19 Pandemic
}

Getrude C. AH GANG

https://doi.org/10.18662/wlc2021/01

How to cite: Ah Gang, G. C. (2021). Psychological Well-being of First-year Psychology Students amid the COVID-19 Pandemic. In A. Sandu (vol. ed.), Lumen Proceedings: Vol. 17 World Lumen Congress 2021 (pp. 01-05). Iasi, Romania: LUMEN Publishing House. https://doi.org/10.18662/wlc2021/01 


\title{
Psychological Well-being of First-year Psychology Students amid the COVID-19 Pandemic
}

\author{
Getrude C. AH GANG ${ }^{1}$
}

\begin{abstract}
University life is always colorful, filled with a plethora of memorable moments, both academic and nonacademic. Amid the COVID-19 pandemic, however, first-year university students' academic experiences might be slightly different from their expectations due to learning being fully conducted online. The COVID-19 pandemic denied first-year students the opportunity to join face-to-face classes and become involved in university activities in a real-life setting. All activities were conducted in a virtual setting, and they could only contact their course mates and lecturers via social media platforms. This derailment of their expectation to experience university in real-life settings may dampen their enthusiasm and impact their motivation and happiness levels. To explore this phenomenon, a study was conducted with 143 first-year psychology students to examine their self-reported motivation and happiness levels before and after seven weeks of online classes. This study included 113 females (79\%) and 30 males (21\%) with a mean age of 20.68 (SD = 1.88). Data collected revealed that students' motivation and happiness levels declined significantly after their online classes. According to their extent of agreement with the single statement "Overall, I am happy with my university life", 48 (33.60\%) students agreed, 76 (53.10\%) were neutral, and $19(13.30 \%)$ disagreed. This study may assist universities and relevant authorities in understanding students' perceptions of dealing with academic life through online classes and related challenges amid the COVID-19 pandemic. Psychological strategies should be considered to enhance first-year students' motivation and happiness levels when faced with online classes in their first semester.
\end{abstract}

Keywords: COVID-19, psychological well-being, motivation, happiness.

\footnotetext{
${ }^{1}$ Ph.D., University Malaysia Sabah, Kota Kinabalu, Malaysia. E-mail: getrudec@ums.edu.my
} 


\section{Introduction}

Various academic and non-academic activities conducted by universities are designed to encourage university students to take charge of their own education and seek out experiential learning opportunities in and beyond the classroom (George \& Thomas, 2020). Some of these activities create significant memories that will be treasured by students long after graduation. These significant memories might be quite different for first-year university students in Malaysia in September 2020 following the Malaysian Ministry of Higher Education's instruction to all higher learning institutions to defer students' on-campus registration due to the increasing number of COVID-19 cases. Hence, all universities in Malaysia conducted online registrations for first-year and returning students. University students who experienced shutdowns and quarantines instead of the anticipated adventures of an in-person campus learning environment may find their expectations further thwarted by the realities of online learning, such as unstable internet connections, a noisy home environment, and the academic workload. For university students in the rural areas, internet connection is a major issue, particularly students in Sabah, where 52 percent of students have a problem accessing the internet because of a lack of infrastructure (Harian, 2020). This may cause insecurity and stress when students lose their connections for online learning. Students perceive that they miss out on the whole college experience by not being involved in campus life (Verena, 2020). To elucidate these phenomena, a study was conducted focusing on students' motivation and happiness levels before and after experiencing online classes for seven weeks of their first semester.

\section{Literature Review}

Past studies revealed that in the era of the COVID-19 pandemic, many students encountered challenges in engaging with online learning. For instance, Selvanathan et al. (2020). found that university students from 12 public and private universities in Malaysia indicated higher dissatisfaction with online teaching methods used during the COVID-19 pandemic. For students in East Malaysia, internet connectivity is one of the most prominent problems in engaging with online learning, besides other problems such as too many different online teaching methods used by various lecturers, a limited broadband data allowance, and a lack of technical skills in using online learning methods (Chung et al., 2020). Another study by Quirk and Quirk (2020) revealed other common difficulties faced by first-year students, such as connecting with new course material and their course mates, meeting academic challenges, and having a productive at-home learning environment. These challenges are faced by most university students globally, as revealed by Browning et al. (2021); from late February to mid-May 2020, students from seven universities in the United States experienced a lack of motivation, anxiety, stress, and isolation due to social distancing, educational changes, and going out less. 


\section{Methodology}

The study is based on a research survey in which first-year students were invited to participate and complete a survey using Google Forms. Data collection was performed seven weeks into the semester. The duration of seven weeks is considered a high-risk transition period for first-time learners, as stated by Krause et al. (2005). Participants were first-time students who had never experienced living on campus and engaging in face-to-face university classes.

\section{Instruments}

A questionnaire consisting of 14 items was used in this study to gather participants' demographic data. Each section, both motivation and happiness, consisted of two items to measure students' motivation and happiness levels before and after they engaged in online classes. Motivation and happiness levels referred to two points, before and after students experienced online classes. They were asked to rank the level of their motivation in relation to the question "How would you describe your motivation level before you were involved in any online classes in your university?" on a Likert scale of $1-10$, where $1=$ No motivation at all, $10=$ Very highly motivated, and $5=$ fifty-fifty. The happiness level was measured based on the question "How would you describe your level of happiness before you attended any online classes in your university?" and was also rated on a scale of $1-$ 10 , where $1=$ Not happy at all and $10=$ Very happy. The same questions were used to ask students to rank their motivation and happiness levels after receiving their classes online. The test and retest reliabilities for motivation and happiness levels were assessed before and after engaging in online courses, and they showed high reliability values; for motivation, it was .90 and for happiness it was .80 .

\section{Results}

Analysis of the demographic data showed that a majority of participants were female, $113(79 \%)$, and $30(21 \%)$ were male. Their mean age was $20.68(\mathrm{SD}=1.88)$. It was found that there was a significant difference in students' motivation before and after engaging in online classes in the new semester $(\mathrm{t}(142)=4.81, \mathrm{p}<.01)$, using the paired sample t-test analysis. The mean level of motivation before was 7.23 ( $\mathrm{SD}=$ $1.90)$ and after was $6.20(\mathrm{SD}=1.86)$. Similarly, there was a significant difference in students' level of happiness before and after engaging in online classes in the new semester $(\mathrm{t}(141)=6.73, \mathrm{p}<.01)$, using the paired sample $\mathrm{t}$-test analysis. The mean level before was $7.71(\mathrm{SD}=1.90)$ and after was $6.20(\mathrm{SD}=1.86)$.

\section{Discussion}

The current study showed that first-year students' motivation levels declined after engaging in online courses in the seven weeks of the first semester. An unstable internet connection that often interrupted their attention and 
concentration may be one of the factors contributing to lowering their motivation; not every student has the same quality of technical facilities and internet connection. In addition, adapting to the new learning environment at home with distractions, such as noise, and competing with siblings and other family members for computer use can also affect motivation. Therefore, they must manage their time effectively between household chores, assignments, and online exams, and this may increase their workload. A study by Quirk and Quirk (2020) revealed that one third of students commented that their workload sharply increased, which may lead to frustration and decreased motivation. Besides happiness, the fundamental changes to the nature of university students' educational experience amid the COVID-19 pandemic have increased the load on students' mental health (Browning et al., 2021). Most students confirmed that they have had issues with anxiety, depression, fear of contagion, and ambivalence due to this pandemic.

\section{Conclusion}

This study revealed that first-year psychology students' motivation and happiness levels declined significantly after engaging in online courses brought on by the COVID-19 pandemic. Learning from home can be a struggle because students must also juggle their classes with housework. Studying at the university instead is beneficial because students can fully concentrate on their academic tasks and have more opportunity to utilize academic resources. For future research, it would be beneficial to explore students' perceptions of their lecturers' strategies in retaining their students' motivation and happiness levels. This could enhance students' motivation and happiness levels and keep students engaged actively and effectively in online learning. Online learning may well have to be faced in their second semester and potentially even after the COVID-19 pandemic, as suggested by Verena (2020).

\section{Acknowledgement}

Thank you to all first-year psychology students who participated in this study. Your contribution means a lot for me.

\section{References}

Berita Harian Online. (2020, May 8). 52 peratus pelajar Sabah tiada akses internet $[52$ percent of Sabah students do not have internet access], https://www.bharian.com.my/berita/nasional/2020/05/686499/52-peratuspelajar-sabah-tiada-akses-interne

Browning, M. H. E. M., Larson, L. R., Sharaievska, I., Rigolon, A., McAnirlin, O., Mullenbach, L., Cloutier, S.,Vu, T. M., Thorsen, J., Reigner, J., Metcalf, E. C., D’Antonio, A., Helbich, M., Bratman, G. N., \& Alvarez, H. O.(2021) Psychological impacts from COVID-19 among university students: Risk factors across seven states in the United States. PLoS ONE, 16(1), e0245327. https://doi.org/10.1371/journal.pone.0245327 
Chung, E., Subramaniam, G., \& Dass, L. C. (2020). Online Learning Readiness Among University Students in Malaysia Amidst COVID-19. Asian Journal of University Education,16(2),46-58 https:// files.eric.ed.gov/fulltext/EJ1267359.pdf

George, G., \& Thomas, R. M. (2020). Quarantined effects and strategies of college students-COVID-19. Asian Education and Development Studies, 10(4), 565-573. https://doi:10.1108/AEDS-04-2020-0054

Krause, K., L., Hartley, R., James, R., \& McInnis, C. (2005). The first-year experience in Australian universities: Findings from a decade of national studies. Australian. Department of Education, Science and Training. https: / doi=10.1.1.723.8190\&rep= rep1\&type $=$ pdf

Quirk, J. M., \& Quirk, J. P. (2020, July 29). What Incoming First-Year Students Want Online Learning To Be. EDUCAUSE Review. bttps://er.educause.edu/articles/2020/7/whatincoming-first-year-students-want-online-learning-to-be

Selvanathan, M., Hussin, N. M., \& Azazi, N. A.(2020). Students learning experiences COVID-19: Work from home period in Malaysian Higher Learning Institutions. Teaching Public Administration. https://dx.doi.org/10.1177\%2F0144739420977900

Verena, D. (2020, October 26). $1^{\text {st }}$ year students tackle unique challenges posed by remote semester. The State News. https://statenews.com/article/2020/10/first-year-studentstackle-unique-challenges? $\mathrm{ct}=\mathrm{content}$ open $\& \mathrm{cv}=\mathrm{cbox}$ featured 